\title{
Health education, obesity and the making of citizens
}

\author{
Claes Malmberg ${ }^{*}$ (D) Anders Urbas and Tomas Nilson
}

\begin{abstract}
This article discusses the socioscientific issue of obesity in relation to citizenship and democratic politics. It is structured in three parts: a) a theoretical part that elaborates on health as an individual and/or societal problem and the concepts of politics, democracy and citizenship; b) an empirical part on how responsibility for obesity is treated in Swedish teaching materials for science and health education; and c) a discussion where the empirical results are analyzed in relation to the theoretical framework used and the implications for future health education with regard to individual responsibility, citizenship and democracy are addressed. The analysis of the teaching materials reveals a strong focus on the individual's responsibility for obesity, formulated through explicit prescriptions and recommendations on how to think and act in everyday life. The implication is that the individual is made into the key actor in solving the problem of obesity. This predominantly individual perspective on solutions is problematic since a strictly individual perspective obscures the political dimension of obesity. Furthermore, the individualization and depoliticization of obesity in teaching materials contribute to and reinforces an ongoing erosion of citizenship and democracy.
\end{abstract}

Keywords: Socioscientific issues, Health education, Obesity, Democracy, Responsibility, Teaching materials

\section{Introduction}

For several decades, scholars have discussed the function of science education. At the heart of this discussion is the emphasis either on science for science's sake or on science for citizenship and democracy. Douglas Roberts (2007) outlines two different views: Vision I and II. The goal in Vision I is science literacy, that is, knowledge within the scientific disciplines. In Vision II, the goal is scientific literacy, that is, the creation of the ability to use scientific knowledge to handle complex societal issues or, in other words, to be an informed citizen. Vision II is a democratic and inclusive form of science education. It has taken many different shapes in science education research and policy documents over the last three decades. The science-technology-society (STS) movement was followed by, e.g., "science-technology-citizenship" (Kolstø, 2001), "socioscientific issues" (SSI) (Ratcliffe \& Grace, 2003; Zeidler, Sadler, Simmons, \&

\footnotetext{
* Correspondence: claes.malmberg@hh.se

Halmstad University, Box 823, SE-301 18 Halmstad, Sweden
}

Howes, 2005), the "public understanding of science" (Solomon, 1992), "humanistic science education" (Aikenhead, 2006) and, recently, by "Science|Environment|Health" (S|E|H) (Zeyer \& Dillon, 2014, 2019). These directions all involve a drive towards scientific literacy and call for interdisciplinary science education, not only among science subjects but also between science, the humanities and social science. Sadler (2004) proposed SSI as a way to open up science education as a practice where students' identities can be expressed as part of their everyday life. For this reason, working with SSI is characterized by making school science important and usable outside the classroom and outside the scientific discourse.

If we as educators want to leverage SSI to promote practices and understandings that support development of students as informed and capable citizens, then we ought not strip away the contextual realities of these issues that confer meaning and generate 
student interest. (Sadler \& Zeidler, 2009, pp. 912913).

More recently, Zeidler, Herman, and Sadler (2019) have brought together new trends in SSI research involving socioscientific reasoning, socioscientific perspective taking and informal and place-based contexts. The ever more complex societal problems facing us require interdisciplinary science education with such capacities.

Furthermore, topics within the $\mathrm{S}|\mathrm{E}| \mathrm{H}$ and SSI approaches are controversial, rife with moral tensions (Zeidler et al., 2019), and characterized by both descriptive facts and normative values, thus making them both scientific and political. This article will elaborate on the political and democratic dimensions of $\mathrm{S}|\mathrm{E}| \mathrm{H}$ and SSI. To that end, we use our ongoing research on responsibility for obesity. Therefore, this study contributes to the discussion of new directions in science education research (Liu \& Wang, 2019; Zeidler et al., 2019; Zeyer \& Dillon, 2019). It explores whether responsibility for obesity is individualized and depoliticized in Swedish schools and discusses what kinds of citizenship and democracy are thus constructed. The empirical material consists of teaching materials that are used by teachers in Swedish schools in the subjects of biology, health pedagogy, physical education and health, and science.

This article is structured in three parts. The initial part is theoretical. First, we discuss health as an individual and/or societal problem; second, we elaborate on the concepts of politics, democracy and citizenship. The next part is empirical and consists of a presentation of our research and our empirical results on how obesity is treated in Swedish teaching materials. We focus on whether the causes of and solutions to obesity are described as individual and/or societal since these dimensions are the foundation of responsibility. The last part discusses the empirical results in relation to the theoretical framework consisting of politics, democracy and citizenship. We discuss what forms of citizenship and democracy are constructed in the Swedish teaching materials for science and health and the implications for future health education.

\section{Individualization, global health problems and schools}

In recent decades, Western societies have undergone major changes in regard to the location of responsibility. Within a wide range of societal areas, a shift from democratic politics to individual responsibility has occurred (Brown, 2015; Miller \& Rose, 2008; Mouffe, 2005; Nordgren, 2003, 2010). The focus on individual responsibility rather than democratic politics is described using labels such as "individualization", "depoliticization" and "responsibilization" (Soneryd \& Uggla, 2015), which are often connected to the notion of a neoliberal rationality and what Wendy Brown (2015) calls 'Undoing of the Demos'.

The transition from democratic politics to individual responsibility is also prominent within health. Robert Crawford (1980) labeled this phenomenon "healthism". Central to healthism is that the fact that it solicits the individual and locates the determinants of health and the solutions to health problems at the level of the individual. Health becomes individualized and depoliticized, detached from social and political factors. This is the case even though health problems are to a large extent caused by social factors and, therefore, are often better served by political solutions (e.g., Marmot, 2015; Wilkinson \& Pickett, 2011, 2018).

The Lancet Commission report The Global Syndemic of Obesity, Undernutrition, and Climate Change (Swinburn et al., 2019) singles out obesity as one of three global challenges. The report questions the predominant idea that individuals are personally responsible for health-related behavior and states that health and health behavior are strongly influenced by the social environment. This statement is in line with what Michael Marmot writes: "The social distribution of obesity and overweight within and between countries should give pause to those who think of health only in terms of personal responsibility" (p. 66).

Although health has generally improved over the last several decades, the health inequalities both between and within countries are increasing (e.g., Berkman, 2009). It is evident that health outcomes fall along a social gradient, showing that at every step on the socioeconomic ladder, poorer people have poorer health (Marmot, 2015; Wilkinson \& Pickett, 2011). Furthermore, obesity is generally increasing globally (Swinburn et al., 2019).

There are many different societal institutions that are important for engaging citizens in health, society and politics. The educational system is probably the most important. In short, how young people perceive themselves and society - as solitary individuals or as democratic citizens - depends to a large extent on what issues are put on the agenda and how they are framed in schools. Schools are one of the most important institutions in the making of citizens, i.e., people who are involved in society, are interested in and participate in democratic politics (Amnå, Ekström, \& Stattin, 2016). This point is clearly manifested in political decisions about our educational system. One main task of schools, at least insofar as this task is expressed in the Swedish Educational Act (SFS, 2010:800) and other documents that regulate the Swedish educational system, is to develop pupils into active, competent and responsible individuals and democratic citizens. 
Despite the explicit formulations in the Swedish Educational Act, the extent to which schools actually contribute to making democratic citizens is unclear. The question is if and how health education entails societal and political perspectives. This question is discussed by Katie Fitzpatrick (2016). Discussing the purpose of health education, she says that two different and competing approaches appear - education about health, on the one hand, and about making students healthy, on the other hand. The tension is unresolvable since the educational norm is to deal with actual health problems and health promotion with the aim of making pupils healthy. In Katie Fitzpatrick's words, health education is caught in an "ethical bind" (2016) that opens up a moralistic paradigm (Jensen, 1997) characterized by the cultivation of a pedagogy aiming at behavioral change. This type of strategy easily creates a focus on individual responsibility for health issues rather than a focus on democratic politics.

This focus on individual responsibility stands in contrast to a statement issued by the WHO asserting that the social determinants of health $(\mathrm{SDOH})$ need to be part of health literacy, i.e., health education needs to include skills related to, for example, accessing, understanding and communicating information on the SDOH (Commission of Social Determinants of Health, 2008). According to Nutbeam (see Smith, Nutbeam, \& McCaffery, 2013), health literacy is divided into three levels: functional health literacy, interactive health literacy and critical health literacy. The third level is described as follows:

Critical health literacy reflects the literacy and numeracy skills that support critical reflection on information or advice received, including recognition of the influence of wider social determinants of health. These include the ability to obtain, understand and critically appraise different sources of information, and the ability to engage in shared decision-making. (Smith et al., 2013, p. 1013).

This emphasis on the SDOH has led to the founding of organizations, e.g., Just Health Action in the Pacific Northwest of the USA. The health pedagogy of such organizations (Mogford, Gould, \& DeVoght, 2010) is not only "critical" but also interactive and inspired by Paulo Freire's pedagogy of the oppressed. They conceptualize critical health pedagogy as knowledge related to teaching the $\mathrm{SDOH}$, activities that help students find their own traits based on the $\mathrm{SDOH}$ and actions for development and implementation to increase health equity. This approach is a promising example of how the content of health education can be widened.

\section{Politics, democracy and citizenship}

Our theoretical perspective is based on the distinction between individual and political responsibility (Malmberg \& Urbas, 2019; Urbas \& Malmberg, 2019). We use this distinction when analyzing how responsibility for health (obesity) is portrayed in teaching materials and what kinds of citizenship and democracy are thus created.

As mentioned above, one of the main functions of Swedish schools is to develop pupils into active and participating citizens in a democratic society. This function concerns all school subjects. Specifically, those that treat health issues with their challenges, complexity and convergence of value and knowledge. To discuss the democratic function, a few points regarding politics and democracy need to be clarified.

First, we recognize the relation between politics and democracy, meaning that (the existence or presence of) politics is a prerequisite for democracy. We can have politics without democracy (nondemocratic politics), but we cannot have democracy without politics.

Second, we adopt David Easton's classic definition of politics:" ... what distinguishes political interactions from all other kinds of social interactions is that they are predominantly oriented toward the authoritative allocation of values for a society" (Easton, 1965, p. 50).

Accordingly, for us, politics is about the making of binding decisions (rules, laws and norms) that regulate the lives of members of an association, for example, a state (Dahl, 1989, 2000). Put differently, “... politics is about decisions, collective decisions which are in some way regarded as binding upon a group of people" (Heywood, 2004, p. 52).

Our definition of politics as the governing of an association through decisions that are binding for its members (e.g., Lewin, 2015) differentiates politics from individual decisions, especially those that focus on and concern only the individual. In this sense, politics is a social activity (Hay, 2007; Heywood, 2004). Furthermore, our definition builds on the idea that politics incorporates dimensions such as situations of choice and human capacity for change. If one or both of these dimensions are lacking, either, for example, as a law of nature (e.g., gravitation or thermodynamics) or due to religious/ideological propaganda that makes people believe that "it must be in a certain way" or "there are no alternatives", then there are no politics (Hay, 2007).

Third, we use a classic and simple view of democracy. According to us, democracy is about collective selfgovernance; put differently, about citizens governing the association of which they are members (Dahl, 1989) This aspect is important since there are alternatives - rule by a single person or a group of persons. Wendy Brown describes it as follows: "The idea of the people ruling 
themselves together in a polity is important for many reasons, but not least because the alternative is to be ruled by others" (Brown, 2015, 2019).

The fourth point relates to the important distinction between individual decisions that affect only the individual him- or herself and democratic politics that affects an association. The decisions that an individual makes only on his or her behalf and that are not focused on the authoritative allocation of values for society are not political. The focus on the authoritative allocation of values is important since it differentiates between politics and nonpolitics. This distinction can be illustrated by a related but not identical view that separates manifest political participation from civil participation (which should be understood as latent political participation). Separate from other forms of action, political participation, according to Ekman and Amnå, is "... quite simply all actions directed towards influencing governmental decisions and political outcomes" (Ekman \& Amnå, 2012, p. 289).

Furthermore, manifest political participation, according to Ekman and Amnå (2012), can be differentiated into formal political participation and (legal and illegal) activism. Both formal political participation and activism (extraparliamentary participation) can take individual and collective forms. Examples of formal political participation that are individual include a) voting in elections, b) contacting political representatives and, c) running for or holding public office. Examples of formal political participation that are collective include a) being a member of a political party and b) being active within an organization or a trade union. Examples of activism that are individual include a) signing petitions and b) handing out political brochures. Examples of collective forms of activism include a) involvement in new social movements and b) participation in strikes and demonstrations. These are all legal forms of activism. Both individual and collective activism can also be illegal. Examples include civil disobedience, politically motivated attacks on property and sabotage (Ekman \& Amnå, 2012). Thus, politics and political participation are oriented towards the authoritative allocation of values for society; put differently, they are oriented towards rules, laws and norms that that are binding and that regulate life within an association (Dahl, 1989).

The fifth point positions citizens at the heart of democracy. If democracy is rule by the people, then democracy needs citizens, i.e., people who at least to some degree are involved in society and are interested in and participate in politics. Citizen participation in politics is often seen as a core element in democracy (van Deth, 2014) since it means - or at least should mean - that the rules, laws and norms that regulate life within an association are decided by citizens (Dahl, 1989, 2000; Dalton, 2008).
The question, then, is how people - particularly young people - become citizens, i.e., persons who are involved in society, are interested in and participate in politics. In this regard, one crucial societal institution is the educational system, as mentioned above, since it affects the norms and knowledge of young people. One can claim that schools are the most important institution in the making (or unmaking) of citizens (Amnå et al., 2016). How urgent and challenging issues such as obesity are framed in schools affects how young people view these issues (as personal or political), themselves (as individuals or as citizens), action (as individual or political) and society (as given or as changeable). Therefore, it is important to analyze how the causes of and solutions to and, thereby, the responsibility for health issues (in our case, obesity) are portrayed in schools.

\section{Obesity in Swedish teaching materials}

This empirical study analyzes how responsibility for obesity is treated in the teaching materials used by teachers in Swedish schools. The study is guided by our theoretical framework and the following research question: How is obesity described in Swedish teaching materials for upper secondary schools - as an individual and/ or a societal/political issue? The following are the concrete questions that we seek to answer in this part:

(A) Are the identified and described causes of obesity individual and/or societal/political?

(B) Are the identified and described solutions to obesity individual and/or societal/political?

\section{Method}

For the analysis, this study uses Swedish teaching materials that explicitly address obesity and that are used by teachers in upper secondary schools. We define teaching materials as all text-based materials that teachers use in the classroom, such as literature, textbooks, media and digital tools.

By analyzing the syllabuses of school subjects, as described in the Swedish national curricula for upper secondary schools (Swedish National Agency for Education, 2013), four subjects emerged with specific aims related to health: biology, health pedagogy, physical education and health, and science. Science is a secondary school subject that incorporates the subjects of biology, chemistry and physics. Health is formally coupled with these subjects through the national curriculum and the core content of the individual subject. For biology and science, the "body and health" are a core content; for physical education and health, "health and lifestyle" are the core content, while the core content of health pedagogy is "human health, health-related living habits and various health effects from an environmental perspective". 
Since the study focuses on teaching materials that are actively used by teachers, we first contacted 17 upper secondary schools from a region in western Sweden. In doing so, we identified the subject teachers of the selected subjects. We sent e-mails to all teachers in biology, health pedagogy, physical education and health, and science, asking them to provide us with information on what teaching materials they use in health education. The teaching materials we obtained consist of literature, textbooks, media (newspaper articles), and Internet sources (digital tools for measuring nutrition). The teachers provided us with a total of 50 different teaching materials.

We categorized the teaching materials into the following categories: (1) nonfiction books, 2) school textbooks (biology, health pedagogy, science, and physical education and health), (3) training guides, (4) articles from newspapers, and (5) Internet resources (Table 1).

We excluded teaching materials that lacked information concerning obesity, healthy eating, and related topics. The teaching materials that were excluded dealt with topics such as drug consumption, sex, emergency care, and how to handle athletic injuries. We also excluded teaching materials that we could not properly identify, e.g., URLs that did not exist.

We used a multistep analysis approach. We started by reading the teaching materials in a general way to understand how obesity is described. To enable us to further differentiate the content more precisely, the next step consisted of a systematization of the content related to obesity based on two categories - causes and solutions. Our analysis of the content was based on the previously discussed theoretical framework, i.e., the distinction between individual responsibility, on the one hand, and democratic politics, on the other hand.

\section{Result and analysis}

Our research aim is to analyze how the problem of obesity and its causes and solutions are portrayed in the teaching materials that are used by teachers in Swedish schools. Thus, the materials are treated as a whole to give a comprehensive description of obesity. When appropriate, we refer to specific sources as illustrations of certain analytical categories. All quotes from the teaching materials are translated by the authors.

We use two categories to structure and present our results. The first category covers how the teaching materials describe the causes of obesity, as individual and/or societal/political. The second category covers how the teaching materials discuss solutions to obesity, as individual and/or societal/political.

A - Individual and societal/political causes of obesity

The causes of obesity are described on two levels, the individual and the societal (political). In many cases, the
Table 1 List of teaching material analysed

\section{Nonfiction books:}

Ellervik, U. (2015). Den svåra konsten att leva. Berättelser om evolution, elände och evigt liv. The difficult art of living. Stories of evolution, misery and eternal life]. Stockholm: Fri tanke förlag.

Hansen, A. (2016). Hjärnstark. Hur motion och träning stärker din hjärna. [Brainstrong. How exercise strengthen your brain]. Stockholm:

Fitnessförlaget.

Hassmén, P., Kenttä, G. \& Gustafsson, H. (2008). Praktisk idrottspsykologi. [Practical Sport Psychology]. Stockholm: SISU idrottsböcker.

Jensen, F. \& Eliss Nutt, A. (2016). Tonårshjärnan: en hjärnforskares guide till att förstå och bemöta tonåringar. [The Teenage Brain: A brain researchers' guide to understand and address teenagers]. Stockholm: Massolit.

\section{Textbooks:}

Axelsson, A.-K. (2016). Hälsopedagogik. [Health education]. Stockholm: Sanoma utbildning.

Henriksson, A. (2016). Synpunkt: naturkunskap. 16. (2. uppl.) [Viewpoint: Science. 1b. (2nd ed.)]. Malmö: Gleerup.

Johansson, B. (2012). Idrott och hälsa. (5. uppl.) [Physical education and health. (5th ed.)]. Stockholm: Liber.

Kirsebom, L. (2012). Insikt. Naturkunskap 1b. [Insight. Science 1b.] Stockholm: Natur och kultur.

Obing, R. (2011). Frank blå: naturkunskap. 1a1. (2. uppl.) [Frank Blå: Science. 1a1. (2nd ed.)]. Stockholm: Liber.

Paulsson, J. \& Svalner, D. (2014). Idrott och Hälsa 1\&2. [Physical education and Health 1 \& 2]. Malmö: Roos \& Tegnér.

Phillips, T. (2016). Hälsopedagogik. (2. uppl.). [Health Education. (2nd ed.)]. Malmö: Gleerups.

Vinnare i långa loppet: tränings- och tävlingslära i specialidrott. (1. uppl.) (2011) [Winner in the long run: training and competition in special sports. (1st ed.)]. Stockholm: SISU idrottsböcker.

\section{Training guides}

Akraka, M. (2016). Den magiska milen. [The magic mile]. Stockholm: Nordstedts.

Ketola, J. \& Gölevik E. (2015). Gymmet utanför dörren. [The gym outside the door] Kristinehamn: Norlén \& Slottner.

Ketola, J. \& Lundberg, A. (2013). Starka fötter. [Strong feet]. Stockholm: SISU Idrottsböcker.

Roberto, P. (2014). Träna en kvart om dagen med Paolo Roberto. [Exercise a quarter of an hour a day with Paolo Roberto]. Stockholm:

Fitnessförlaget.

Tonkonogi, M. \& Bellardini, H. (2012). Ålderanpassad fysisk träning för barn och ungdom. [Age-adjusted physical training for children and adolescents]. Stockholm: SISU Idrottsböcker.

\section{Newspaper articles}

Dagens Nyheter, 2016-10-30. Sockrade påståenden och feta lögner av. Amina Manzoor. [Sugared statements and obscene lies by Amina Manzoor]. Downloaded 2019-12-04 from https://web.retriever-info.com/services/archive/search

Hallandsposten, 2013-06-27. Hemligheten med de blå zonerna av. Cicki Gustafsson. [The secret of the blue zones by Cicki Gustafsson]. Downloaded 2019-12-04 from https://web.retriever-info.com/services/archive/ search

Göteborgs-Posten, 2011-01-07. Samma effekt med vanlig mat av. Nils Svensson. [Same effect with regular food by Nils Svensson]. Downloaded 2019-12-04 from https://web.retriever-info.com/services/archive/search

\section{Internet sources}

www.muscles.se

www.nutritiondata.se

causes described as a question of lifestyle. A prominent feature is that obesity problems are caused by food intake and lack of exercise. One textbook states that "we eat too much, too often and the wrong things" (Kirsebom, 2012, p. 144), and it continues by describing the 
fact that our food consumption has led to obesity among $50 \%$ of all adults, which in turn causes diabetes, heart disease, and certain cancers, primarily in the gastrointestinal tract (Kirsebom, 2012). Other textbooks relate obesity to our lifestyle and to our eating habits. One textbook concludes that "Bad eating habits can result in malnutrition. You can be obese and at the same time suffer from malnutrition" (Johansson, 2012, p. 14). The question of habits is also highlighted. One book claim that in many cases, obesity results from bad eating habits to the extent that people, who may know what and how to eat, in many cases do not have the ability to change (Phillips, 2016). This question of what and how much we eat and its consequences are also contextualized as illustrated in the following example:

Not long ago, Sweden was a poor country. Many struggled daily to get enough food. Very few people had problems that arose from eating too much. Many ate unbalanced meals because they could not afford or have the opportunity to choose something else.

For most of us today, it is, in principle, possible to eat healthy and balanced meals. However, this often looks different in practice. We eat larger portions than before, and we eat more often. The consumption of candy, soft drinks, ice cream, fast food, and snacks is higher than ever. At the same time, we move less. The result is that many are overweight and ill. (Kirsebom, 2012, p. 152).

Accordingly, the point advanced in this textbook is that society has changed and that we now eat more unhealthily (snacks, candy, ice cream) than we used to. It is also said that, today, we move our bodies less (Henriksson, 2016). The implication of our modern lifestyle is, among other things, obesity.

In some cases, the shape and look of our bodies are depicted as a matter of individual choice and character. One training guide notifies the reader that there is a relation between what we do in everyday life and how we look. The argument is not that diet should be a choice but that we cannot expect to be fit and healthy if we eat cake 7 days a week even though we exercise (Roberto, 2014). The question of lifestyle and choice is sometimes complemented by heredity. One textbook states that obesity and overweight are affected by our lifestyle and our heredity, i.e., our genes. The argument is that we have different genes and that the genes are affected in different ways by what we eat (Axelsson, 2016).

According to the teaching materials, obesity is closely related to the attributes of modern society. In many ways, the teaching materials are united by the view that the abundance and availability of food and drink, especially candy, junk food and the wrong kind of cheap, highly caloric food, are a central cause of obesity. This view is sometimes related to another feature of contemporary society, namely, lack of exercise, and the following passage is an example that expresses this view:

For most people in the world's richest countries, food is constantly available, and we do not have to move very much. In this situation, the body's ability to store fat has been turned into a disadvantage. In Sweden and in many other countries, we now see more problems with the increase in overweight. Overweight is due to eating more than the body burns. (Henriksson, 2016, p. 198).

Another textbook connects obesity to societal aspects of socioeconomic differences, for example, the level of education of the mother. According to the textbook, children who have mothers with only basic education are more obese than children with highly educated mothers (Axelsson, 2016, p. 62). The same textbook also relates obesity to the demands of school and society in general insofar as these demands create stress that affects one's weight (Axelsson, 2016).

To sum up: The teaching materials address various causes of obesity. Some causes are individual, such as the choices people make in their everyday lives, while some causes are societal or political, such as the abundance and availability of food and drink as well as socioeconomic differences. In other words, from the perspective of causes, obesity is treated both as an individual and as a societal and political phenomenon.

\section{$B$ - Individual solutions to obesity}

The causes of obesity advanced in the teaching materials exist on two different levels, the individual and the societal/political. However, in regard to the solutions to obesity, the findings indicate a major difference. The overall picture shows that the solutions advanced rest exclusively with the individual, not society or politics.

However, there are a few exceptions regarding solutions. Two textbooks put health into a larger context and discuss public health, which naturally includes the problem of obesity, in relation to different levels, i.e., the individual, the societal and the political (Axelsson, 2016; Philips, 2016). Let us consider two examples from these textbooks: One of them highlights the importance of schools and meals in school in respect to healthy eating (Axelsson, 2016).

The increase in the proportion of overweight and obesity has stopped, but it has never before been as high as now. The effects of the disease will appear later. Education and health information should reverse the development of overweight and obesity. Schools have worked to ensure the quality of food, and it has shown positive results. In the School Act 
(2010: 800), it is a requirement for school meals to be nutritious. (Axelsson, 2016, p. 249).

The other textbook points to, among other thing, the importance of the public sector and authorities in informing people and, therefore, changing, for example, their bad eating habits (Phillips, 2016).

However, these two examples are exceptions. The predominant descriptions of solutions to obesity and the main recommendations regarding obesity are formulated on the individual level. The teaching materials contain a rich set of recommendations and prescriptions for how we ought to live to remain healthy. One typical solution to health problems, including obesity, is to exercise and maintain a varied diet. Such a diet should not consist of energy-rich and nutrient-poor foods. Instead, we should eat whole grains, vegetables and fruits and choose more healthy fats. Additionally, we should eat less meat, especially red meat. The recommendations are based on the fact that as a result of today's eating habits and consumption, half of all adults are overweight or obese (Kirsebom, 2012). The same type of description and recommendation is formulated in one textbook as follows:

Good meal routines are important for preventing obesity. One should eat the main meals at the same time each day. Then, the urge to eat between meals will not be so great. You should also start the day with a decent breakfast. The risk of overweight increases if you eat small portions for breakfast and lunch but larger portions in the afternoon and evening. It is good if you can choose a plate model so that you do not miss vegetables and root vegetables. Fruit is a good alternative as a snack. One should also reduce fast carbohydrates to benefit from slow carbohydrates. Everyone needs to move daily. A training session per week is not enough. For many, walking or cycling to school instead of going by car or bus is an option. One can also limit one's television or computer time so that one can take a walk or engage in other physical activities. (Henriksson, 2016, p. 199).

The presence of dietary advice and different types of lists of when, how, and what to eat is a typical feature in the teaching materials regarding our consumption of food and drink (e.g., Johansson, 2012). In one training guide, seven recommendations, including eating a large amount of fruits and vegetables, are proposed (Akraka, 2016), while another guide highlights the importance of eating nutritious food to refuel our energy levels (Ketola \& Gölevik, 2015). These types of lists and recommendations are common in the teaching materials, and they sometimes coincide with the recommendations of national authorities. For example, one textbook highlights that, on a daily basis, we regularly encounter recommendations on what to eat and drink, not least through media. The textbook also makes the discrepancies in recommendations visible, clarifying that the Swedish official recommendations are based on requests made by the National Food Agency of Sweden to make us "eat more vegetables, fruit, and fish". It concludes by stating that the "most important thing is that you are aware of what you eat and how it affects you" (Paulsson \& Svalner, 2014). The list from the National Food Agency of Sweden is also present in other textbooks (Kirsebom, 2012), and the following points are made:

- Eat half a kilo of vegetables and fruit every day;

- Choose low-fat dairy products;

- Eat fish three times a week;

- Use liquid margarine and oil instead of butter;

- Choose whole-grain varieties when you eat bread, grain and cereals;

- Eat less meat;

- Consume less candy, pastries, ice cream and soft drinks; and

- Exercise for at least $30 \mathrm{~min}$ a day.

The focus on the individual is also predominant in other parts of the teaching materials. Some focus on training and dietary measures (www.muscles.se, www. nutriondata.se) and contain training tips, recipes for healthy food, articles such as "Lose weight - ten tips for lasting weight loss" (www.muscles.se) and tools for measuring one's food intake (www.nutriondata.se).

The same focus is also present when the teaching materials explicitly refer to obesity. One textbook discusses obesity and our eating habits and highlights 10 recommendations. Among others, they include (1) eating more fruits and vegetables, (2) using a medium-sized plate to obtain the right amount of food, (3) eating less and not taking a second helping, (4) eating regularly and (5) consuming less candy, soft drinks and alcohol or avoiding them altogether (Axelsson, 2016).

The descriptions and recommendations of how and what to eat are complemented by tools for monitoring one's weight. The BMI (body mass index) is frequently described in the teaching materials. One textbook starts by asserting that we need to have a balance between what we eat and the energy that we use, and it then continues by describing the BMI as a tool for monitoring our weight (Axelsson, 2016). A related theme is how to maintain one's weight. For example, one textbook discusses whether people should or should not go on a diet and concludes that the best way to lose weight is to exercise regularly. According to the same textbook, one 
way to lose weight is to walk to school, if a person wants to lose stomach fat, then he or she should cycle or swim. The textbook mentions that the best way to monitor stomach fat is to regularly measure it (Johansson, 2012).

To sum up: When the teaching materials highlight solutions to obesity, the majority of such solutions are oriented towards the individual him- or herself. The focus on individual responsibility is formulated through explicit prescriptions and recommendations on how to think and act in everyday life. The individual is thus made into the key actor in solving the problem of obesity.

\section{Discussion}

In this part, we discuss the empirical results based on our theoretical framework. That is, we elaborate on the implications that the empirical results have for the function of schools to socialize students to become competent individuals and citizens who participate in democratic politics. We use our theoretical framework consisting of politics, democracy and citizenship.

When we consider our theoretical framework of politics, citizenship and democracy, the predominantly individual perspective on solutions to obesity in the teaching materials becomes problematic. The reason is that the strictly individual perspective in the teaching materials obscures the political dimension of obesity. Obesity is described, and consequently constructed, as an individual, not public, social or governmental, concern. The effect is an invisibilization of politics, that is, a depoliticization. A political perspective would entail the formulation of solutions (as well as preventions) aiming at change at the societal level through political action. Additionally, a political perspective would focus on what has previously been described as manifest political participation and/or activism (Ekman \& Amnå, 2012). This means that the focus would be on what Easton (1965) calls authoritative allocation of values for society or, in Heywood's (2004) formulation, a focus on collective decisions that are regarded as binding upon a group of people. In this way, the teaching materials would also be in line with the critical health literacy approach promoted by Smith et al. (2013) and the WHO (Commision on Social Determinants of Health, 2008). However, this is not the case, and in fact, the opposite is the case. In regard to solving (or preventing) obesity, responsibility rests entirely with the individual him- or herself.

The depoliticization of obesity in the teaching materials is quite profound. Politics, as previously discussed, incorporates important dimensions such as choice and the capacity for change. However, these dimensions are not at the forefront when obesity and its (societal and political) causes and solutions are discussed. Instead, the societal and political causes are depicted as predetermined and as not possible to change. Put differently, the societal causes are depicted as given and as nonchangeable through political action such as any type of manifest political participation and/or activism. According to the teaching materials, it is the individual him- or herself, not the societal and political context, that can be changed. In line with our previous research (Malmberg \& Urbas, 2019), we can assert that the teaching materials are characterized by solutions based on individual change and adaption to the societal context rather than on collective action and politically induced change. In essence, this approach is a depoliticization of obesity and is in line with what research has labeled healthism and responsibilization.

Furthermore, the individualization and depoliticization of obesity in the teaching materials contribute to and reinforce an ongoing erosion of citizenship and democracy. The strict focus on individual responsibility can be viewed as what Zeidler et al. (2019) call an educational deficit that inhibits people from becoming active and knowledgeable citizens. Put differently, the consequence of this strictly individual focus is, as Wendy Brown (2015) expresses, an undoing of demos. The teaching materials contribute to the unmaking, rather than the making, of citizens.

\section{Implications}

Our position is not that the recommendations and prescriptions advanced in the teaching materials are wrong or contradict what we know about health and obesity. Rather, the point that we are making is that the strictly individual perspective must be complemented by a societal and political perspective. Such a complement is important since many causes of obesity are societal/ political and therefore need political solutions. It is also important from the perspective of citizenship and democracy. Swedish schools should contribute to the making of citizens and democracy. Whether such a contribution is made, however, is unclear. The strict focus on individual responsibility creates, contributes to and reinforces what we call "the paradox of responsibility". The paradox does not in any way promote citizenship and democratic politics. Instead of empowering young people with a toolbox of possible political action, such as manifest political participation, for example, contacting political representatives, and/or activism, for example, involvement in social movements, the strict focus on individual responsibility places the entire burden on the individual, creating what Albert Zeyer and Justin Dillon, within the field of sustainable development, describe as eco-depression: "The paradox of responsibility charges them with a mission they feel that they cannot accomplish. The result is an ecodepression" (Zeyer \& Dillon, 2019, p. 6). 
The idea of eco-depression is important since it informs us that we can discuss health depression in the same manner. Placing the entire burden of solving health problems on the young individual simultaneously as societal support and political options are withdrawn creates for the individual a highly challenging situation that might lead to a feeling of powerlessness and health depression. Health issues should, in order to avoid this, therefore be treated from a broader public health perspective, e.g., through examples of how political decisions, rules, regulations and activism have resulted in and affected public health. Health issues should to a higher degree be treated as a societal, collective and political concern without forgetting the individual dimension. Schools need to make young people understand that it is possible to use both direct/indirect regulations (such as statutory nutritious food in school, bans on commercials for unhealthy food in educational settings, taxes on and/or subsidies for the beverages and food that young people consume) and different types of recommendations and instructions (such as instructions on how to drink and eat healthily) when dealing with obesity. Focusing on democratic politics to a greater degree would lessen the burden placed on young people and counteract health depression. It would also contribute to the making of citizens.

In this respect, the educational system and schools are important. The same holds true for science education fields such as sustainability, health, genetically modified organisms (GMOs), and sex education. Rather than producing only solitary individuals who are able to make individual decisions for themselves, school should also produce citizens: people who are involved in society, are interested and participate in democratic politics. To contribute to the making of citizens, the paradox of responsibility must be resolved, meaning that health (in our case, obesity) is treated as a concern for the individual and democratic politics. This treatment requires an interdisciplinary approach. However, it might be difficult for science teachers to leave their "comfort zone", that is, their science expertise. Therefore, it is important for research on $\mathrm{S}|\mathrm{E}| \mathrm{H}$ and SSI to involve teachers and perspectives representing different disciplines and to focus on thematic organization and interdisciplinary teams.

\section{Conclusion}

The main conclusion of this article is that with regard to health in Swedish teaching materials in the subjects of biology, health pedagogy, physical education and health, and science the predominant focus on individual responsibility rather than on democratic politics obscures the societal and political dimensions of health. The effect is an individualization and depoliticization of health that is counterproductive when considering the function of education: the making of democratic citizens. Thus, this article adds new perspectives to research on $\mathrm{S}|\mathrm{E}| \mathrm{H}$ and SSI.

\begin{abstract}
Abbreviations
BMI: Body mass index; S|E|H: Science|Environment|Health; SDOH: Social determinants of health; SSI: Socioscientific issues; STS: Science-technologysociety; WHO: World Health Organization
\end{abstract}

\section{Acknowledgements}

This article was made possible thanks to support from Halmstad University, School of Education, Humanities and Social Sciences. We are very grateful for all comments on early drafts contributed by associate professor Lars Nordgren and by PhD UIf Petäjä and by our reviewers.

\section{Authors' contributions}

Claes Malmberg carried out part of the collection of empirical data, the analysis of empirical data, and wrote part of the empirical section in the paper. He wrote part of the introduction and theoretical background and the discussion. Anders Urbas carried out part of the collection of empirical data, the analysis of empirical data, and wrote part of the empirical section in the paper. He wrote part of the introduction and theoretical background and the discussion. Tomas Nilson carried out part of the collection of empirical data, the analysis of empirical data, and wrote part of the empirical section in the paper. All authors participated in its design and coordination and helped to draft the manuscript. All authors read and approved the final manuscript.

\section{Authors' information}

C.M. is a professor in Science Education and PhD in Education. He is currently working at Halmstad University, Sweden. His research interests are on cultural and political perspectives on Science Education, Health Education and Education for Sustainable Development.

A.U., PhD in Political Science, is currently working at Halmstad University, Sweden. His research interests are politics, democracy and citizenship in Science Education, Health Education and Education for Sustainable Development.

T.N., PhD in History, is currently working at Halmstad University, Sweden. His research focus on health from a social and cultural perspective.

\section{Funding}

Funded by Halmstad University, Sweden.

Availability of data and materials

Availability of data and materials. All empirical material used are included in Table 1. List of teaching material analysed (see manuscript page 11-12).

Ethics approval and consent to participate

Not applicable.

\section{Consent for publication}

Not applicable.

\section{Competing interests}

No competing interests.

Received: 31 January 2020 Accepted: 24 June 2020

Published online: 13 July 2020

\section{References}

Aikenhead, G. S. (2006). Science education for everyday life: Evidence-based practice. New York: Teachers College Press.

Amnå, E., Ekström, M., \& Stattin, H. (2016). Ungdomars politiska utveckling: slutrapport från ett forskningsprogram. Göteborg: Riksbankens jubileumsfond i samarbete med Makadam.

Axelsson, A.-K. (2016). Hälsopedagogik. Stockholm: Sanoma utbildning.

Berkman, L. F. (2009). Social epidemiology: Social determinants of health in the United States: Are we losing ground? Annual Review of Public Health, 30, 2741.

Brown, W. (2015). Undoing the demos: neoliberalism's stealth revolution, (1st ed., ). New York: Zone Books. 
Brown, W. (2019). In the ruins of neoliberalism. The rise of antidemocratic politics in west. New York: Columbia University Press.

Commision on Social Determinants of Health (2008). Closing the gap in a generation: Health equity through action on the social determinants of health. Final report of the commission on social determinants of health. Geneva: World Health Organization.

Crawford, R. (1980). Healthism and the medicalisation of everyday life. International Journal of Health Services, 10(3), 365-388.

Dahl, R. A. (1989). Democracy and its critics. New Haven: Yale University Press.

Dahl, R. A. (2000). On democracy. New Haven: Yale University Press.

Dalton, J. R. (2008). Citizenship norms and the expansion of political participation. Political Studies, 56, 76-98.

Easton, D. (1965). A framework for political analysis. Englewood Cliffs: Prentice-Hall.

Ekman, J., \& Amnå, E. (2012). Political participation and civic engagement: Towards a new typology. Human Affairs, 22, 283-300.

Fitzpatrick, K. (2016). Critical approaches to health education. In K. Fitzpatrick, \& R. Tinning (Eds.), Health education: critical perspectives. London: Routledge.

Hay, C. (2007). Why we hate politics. Cambridge: Polity.

Henriksson, A. (2016). Synpunkt: naturkunskap 1b. (2. uppl.). Malmö: Gleerup.

Heywood, A. (2004). Political theory: an introduction, (3rd ed., ). New York: Palgrave Macmillan.

Jensen, B. B. (1997). A case of two paradigms within health education. Health Education Research, 12(4), 419-428.

Johansson, B. (2012). Idrott och hälsa. (5. uppl.). Stockholm: Liber.

Kirsebom, L. (2012). Insikt. Naturkunskap 1b. Stockholm: Natur och kultur.

Kolstø, S. (2001). Scientific literacy for citizenship: Tool for dealing with the science dimension of controversial socio-scientific issues. Science Education, $85,291-310$.

Lewin, L. (2015). Statsvetenskapens grunder. (2. uppl.). Lund: Studentlitteratur.

Liu, X., \& Wang, L. (2019). Editorial: disciplinary and interdisciplinary science education research. Disciplinary and Interdiciplinary Science Educaion Research, 1(1), 1-3. https://doi.org/10.1186/s43031-019-0001-1.

Malmberg, C., \& Urbas, A. (2019). Health in school: stress, individual responsibility and democratic politics. Cultural Studies of Science Education, 14, 863-878. https://doi.org/10.1007/s11422-018-9882-0.

Marmot, M. (2015). The health gap: The challenge of an unequal world. London: Bloomsbury.

Miller, P., \& Rose, N. S. (2008). Governing the present: Administering economic, social and personal life. Cambridge: Polity.

Mogford, E., Gould, L., \& DeVoght, L. (2010). Teaching critical health literacy in the US as a means to action on the social determinants of health. Health Promotion International, 26(1), 4-13. https://doi.org/10.1093/heapro/daq049.

Mouffe, C. (2005). On the political. London: Routledge.

Nordgren, L. (2003). Från patient till kund. Intåget av marknadstänkande i sjukvården och förskjutningen av patientens position. Diss. Lund: Lund Business Press.

Nordgren, L. (2010). Mostly empty words - what 'freedom of choice' in health care does. Journal of Health Organization and Management, 24(2), 109-126.

Phillips, T. (2016). Hälsopedagogik. (2. uppl.). Malmö: Gleerups.

Ratcliffe, M., \& Grace, M. (2003). Science education for citizenship: Teaching socioscientific issues. Maidenhead: Open University Press.

Roberto, P. (2014). Träna en kvart om dagen med Paolo Roberto. Stockholm: Fitnessförlaget.

Roberts, D. A. (2007). Scientific literacy/science literacy. In S. K. Abell, \& N. G. Lederman (Eds.), Handbook of research on science education. Mahwah, NJ: Lawrence Erlbaum Associates.

Sadler, T. (2004). Informal reasoning regarding socio-scientific issues: A critical review of research. Journal of Research in Science Teaching, 41, 513-536.

Sadler, T. S., \& Zeidler, D. L. (2009). Scientific literacy, PISA, and Socioscientific discourse: Assessment for progressive aims of science education. Journal of Research in Science Teaching, 46(8), 909-921.

SFS (2010: 800) Skollag. (Swedish Educational Act) https://www.riksdagen.se/sv/ dokument-lagar/dokument/svensk-forfattningssamling/skollag-2010800_sfs-2 010-800.

Smith, S. K., Nutbeam, D., \& McCaffery, K. J. (2013). Insights into the concept and measurement of health literacy from a study of shared decision-making in a low literacy population. Journal of Health Psychology, 18(8), 1011-1022. https://doi.org/10.1177/1359105312468192.

Solomon, J. (1992). Teaching science, technology and society. Buckingham: Open University Press.
Soneryd, L., \& Uggla, Y. (2015). Green governmentality and responsibilization: New forms of governance and responses to 'consumer responsibility'. Environmental Politics, 24(6), 913-931.

Swedish National Agency for Education (2013). Curriculum for the upper secondary school. https://www.skolverket.se/getFile?file=2975.

Swinburn, B. A., Kraak, V. I., Allender, S., Atkins, V. J., Baker, P. I., Bogard, J. R., .. Devarajan, R. (2019). The global syndemic of obesity, undernutrition, and climate change: The lancet commission report. Lancet, 393(10173), 791-846.

Urbas, A., \& Malmberg, C. (2019). Värden, demokrati och lösningar på samhällsproblem - exemplet kost och hälsa. In L. Nordgren, \& K. Hansson (Eds.), Health management - Att skapa vinst och värde i välfärden. Sanoma utbildning: Stockholm.

van Deth, J. (2014). A conceptual map of political participation. Acta Politica, 49(3), 349-367.

Wilkinson, R. G., \& Pickett, K. (2011). The spirit level: why greater equality makes societies stronger. (Rev. and updated [ed.].). New York: Bloomsbury Press.

Wilkinson, R. G., \& Pickett, K. (2018). The inner level: how more equal societies reduce stress, restore sanity and improve everybody's well-being. London: Allen Lane an imprint of Penguin Books.

Zeidler, D. L., Sadler, T. D., Simmons, M. L., \& Howes, E. V. (2005). Beyond STS: A research-based framework for socioscientific issues education. Science Education, 89, 357-377.

Zeidler, L. D., Herman, C. B., \& Sadler, D. S. (2019). New directions in socioscientific issues research. Disciplinary and Interdisciplinary Science Education Research., 1(11), 1-9. https://doi.org/10.1186/s43031-019-0008-7.

Zeyer, A., \& Dillon, J. (2014). Science|Environment|Health - Towards a reconceptualization of three critical and inter-linked areas of education. International Journal of Science Education, 36(9), 1409-1411.

Zeyer, A., \& Dillon, J. (2019). Science|Environment|Health - the emergence of a new pedagogy of complex living systems. Disciplinary and Interdisciplinary Science Education Research, 1(9), 1-10. https://doi.org/10.1186/s43031-0190014-9.

\section{Publisher's Note}

Springer Nature remains neutral with regard to jurisdictional claims in published maps and institutional affiliations.

\section{Submit your manuscript to a SpringerOpen ${ }^{\circ}$ journal and benefit from:}

- Convenient online submission

- Rigorous peer review

- Open access: articles freely available online

- High visibility within the field

- Retaining the copyright to your article

Submit your next manuscript at $\boldsymbol{\nabla}$ springeropen.com 